\title{
МЕХАНІЗМ ЗАБЕЗПЕЧЕННЯ СОЦІАЛЬНОЇ СТАБІЛЬНОСТІ В УМОВАХ ІНТЕНСИФІКАЦІЇ МІГРАЦІЙНИХ ПРОЦЕСІВ
}

\section{MECHANISM FOR ENSURING SOCIAL STABILITY IN THE CONDITIONS OF INTENSIFICATION OF MIGRATION PROCESSES}

\author{
Рущишин Надія Михайлівна \\ доктор економічних наук, доцент, \\ Львівський торговельно-економічний університет \\ ORCID: https://orcid.org/0000-0002-1198-8582 \\ Мульска Ольга Петрівна \\ кандидат економічних наук, старший науковий співробітник, \\ ДУ «Інститут регіональних досліджень імені М.І. Долішнього \\ Національної академії наук України» \\ ORCID: https://orcid.org/0000-0002-1666-3971 \\ Rushchyshyn Nadiya \\ Lviv University of Trade and Economics \\ Mulska Olha \\ Dolishniy Institute of Regional Research \\ of the National Academy of Sciences of Ukraine
}

\begin{abstract}
У статті висвітлено суть соціальної стабільності держави. Охарактеризовано механізм забезпечення соціальної стабільності в державі та його особливості. Представлено модель структурно-функціональної взаємозалежності процесів забезпечення соціальної стабільності в контексті зменшення активності міграційних процесів в Україні. Подано послідовність фрормування механізму забезпечення соціальної стабільності держави в умовах інтенсифікації міграційних процесів. Наведено передумови загострення проблеми соціальної несправедливості в українському суспільстві та зростання міграційної активності населення. Окреслено пріоритетні напрями забезпечення соціальної стабільності в державі та стримування активності населення у сегменті зовнішньої трудової міграції. Визначено напрями структурної модернізації соціальної політики в умовах інтенсифрікації міграційних процесів. Представлено агрегований механізм забезпечення соціальної стабільності держави в умовах інтенсифікації міграційних процесів.
\end{abstract}

Ключові слова: соціальна стабільність держави, соціальна політика, міграційні процеси, механізм в сорері соціально-економічних відносин, трудова міграція.

В статье освещены суть социальной стабильности государства. Охарактеризовано механизм обеспечения социальной стабильности в государстве и его особенности. Представлена модель структурно-фрункциональной взаимозависимости процессов обеспечения социальной стабильности в контексте уменьшения активности миграционных процессов в Украине. Подано последовательность формирования механизма обеспечения социальной стабильности государства в условиях интенсификации миграционных процессов. Приведены предпосылки обострения проблемы социальной несправедливости в украинском обществе и рост миграционной активности населения. Определены приоритетные направления обеспечения социальной стабильности в государстве и сдерживания активности населения в сегменте внешней трудовой миграции. Определены направления структурной модернизации социальной политики в условиях интенсиорикации миграционных процессов. Представлено агрегированный механизм обеспечения социальной стабильности государства в условиях интенсифрикации миграционных процессов.

Ключевые слова: социальная стабильность государства, социальная политика, миграционные процессы, механизм в сфрере социально-экономических отношений, трудовая миграция.

The aim of the article is to study the social stability in the country in terms of intensification of migration processes and the formation of a mechanism for its provision. Establishing effective management processes, forming a high 
level of competitiveness of domestic production and economic complexes and building a strong national economy is impossible without a reliable social base. Ensuring the social stability of the state is a fundamental prerequisite not only for improving the quality of life and improving its well-being, but also minimizing the conflict environment in society, reducing social tensions and increasing the level of satisfaction of citizens' interests. special methods and techniques, in particular: theoretical generalization; system approach; abstract-logical; logical-analytical, etc. The article highlights the essence of social stability of the state. The mechanism of ensuring social stability in the state and its features are described. The model of structural and functional interdependence of social stability processes in the context of reducing the activity of migration processes in Ukraine is presented. The sequence of formation of the mechanism of ensuring social stability of the state in the conditions of intensification of migration processes is given. The preconditions for aggravation of the problem of social injustice in the Ukrainian society and growth of migration activity of the population are given. The priority directions of ensuring social stability in the state and restraining the activity of the population in the segment of external labor migration are outlined. It is noted that ensuring social stability in the conditions of intensification of migration processes is impossible without the implementation of effective tools to de-shadow the functioning of production and economic complexes of the national economy. The strategic basis for ensuring social stability in the context of intensification of migration processes is the formation of a favorable socio-psychological basis for the development of socio-economic relations. The aggregate mechanism of ensuring social stability of the state in the conditions of intensification of migration processes is presented.

Keywords: social stability of the state, social policy, migration processes, mechanism in the field of socioeconomic relations, labor migration.

Постановка проблеми. Налагодження ефрективних процесів господарювання, формування високого рівня конкурентоспроможності вітчизняних виробничо-господарських комплексів і побудова потужної національної економіки неможливі без надійного соціального базису. Забезпечення соціальної стабільності розвитку держави $€$ срундаментальною передумовою не лише підвищення якості життя населення та покращення його добробуту, але й мінімізації конфрліктного середовища в суспільстві, зниження соціальної напруги та зростання рівня задоволеності інтересів громадян. Очевидно, що наявність системних дестабілізуючих впливів на розвиток суспільно-економічних відносин, апріорі, ускладнюють імплементацію механізмів та інструментів досягнення ефективних структурних змін у сегменті забезпечення соціальної стабільності держави.

Домінантну роль серед ірраціональних детермінант стримування процесів забезпечення соціальної стабільності держави посідають негативні тенденції зростання міграційної активності населення, руйнівний характер яких формалізується насамперед у такому: посилення дисбалансів просторово-територіального розміщення населення, загострення міжетнічних і міжрелігійних протистоянь, нівелювання інституту сім'ї та сімейних цінностей, поглиблення проблеми становлення культурної ідентичності українського народу, зростання соціальної напруженості в суспільстві, загострення проблеми розвитку та виховання прийдешніх поколінь, гальмування процесів становлення монолітності нації, перешкоджання фрормуванню середнього класу, погір- шення соціальної структури суспільства, загострення проявів девіантної та опортуністичної поведінки, посилення інертного характеру фрункціонування соціально-комунікаційних взаємозв'язків між учасниками суспільно-економічного обміну. Подолання ідентифікованих деструктивних впливів об'єктивно вимагає обґрунтування науково-прикладних положень щодо фрормування ефективного механізму забезпечення соціальної стабільності держави в умовах інтенсифрікації міграційних процесів.

Аналіз останніх досліджень і публікацій. Дослідження економічної стабільності та зокрема соціальної стабільності в Україні проводились в працях Барної М.Ю. [1]. Питання соціального забезпечення, міграційної політики та міграційних процесів розглядалися в працях Libanova E. [5], Vasyltsiv T., Lupak R., Kunytska-lliash M. [6]. Застосування інструментів стимулювання розвитку IT-сорери України задля мінімізації трудової міграції висвітлено у працях Васильціва Т.Г., Шехлович А., Васильціва В.Г. [7]. Адміністративно-правове регулювання трудової міграції в умовах трансформації економіки України досліджувалося Волоско Я.О. [8]. Аспекти балансування ринку праці в умовах підвищеної міграційної активності населення та фрормування системи соціального захисту трудових мігрантів розглянуто в працях $[9 ; 10]$. Сталий та збалансований розвиток системи національного господарства та зокрема забезпечення соціальної стабільності досліджувалося у працях [12]. Проте, механізм забезпечення соціальної стабільності в умовах інтенсифікації міграційних процесів потребує більш глибшого дослідження. 
Мета статті. Окреслення соціальної стабільності в країні за умов інтенсифрікації міграційних процесів та фрормування механізму її забезпечення.

Виділення невирішених раніше частин загальної проблеми. Проведені дослідження охоплюють питання соціальної стабільності та міграційних процесів в країні, проте постає необхідність окреслення та обґрунтування саме механізму забезпечення соціальної стабільності в умовах інтенсифрікації міграційних процесів.

Формулювання цілей статті (постановка завдання). Основними завданнями статті $\epsilon$ дослідження соціальної стабільності держави, окреслення механізму забезпечення соціальної стабільності в державі та його особливості, представлення моделі структурно-срункціональної взаємозалежності процесів забезпечення соціальної стабільності в контексті зменшення активності міграційних процесів в Україні, окреслення послідовності фрормування механізму забезпечення соціальної стабільності держави в умовах інтенсифрікації міграційних процесів та пріоритетних напрямів забезпечення соціальної стабільності в державі та стримування активності населення у сегменті зовнішньої трудової міграції. А також визначити напрями структурної модернізації соціальної політики в умовах інтенсифрікації міграційних процесів.

Виклад основного матеріалу дослідження. Поняття «стабільність» позиціонується через призму дотримання засад реалізації принципів збалансованості, раціональності, узгодженості та відсутності диспропорцій в структурі розвитку соціальноекономічної системи, що фрормує передумови для забезпечення його стійкого й зрівноваженого фрункціонування в умовах динамічних змін оточуючого середовища та наростаючих викликів й загроз. Своєю чергою, під соціальною стабільністю слід розуміти організацію раціональної структури відносин між учасниками суспільно-економічного обміну, забезпечення якої фрормує передумови для максимізації задоволення інтересів й потреб цих учасників, імплементації базових засад соціальної справедливості розподілу матеріальних благ у суспільстві та гармонійного розвитку кожної особистості. Очевидно, що реалізація механізму забезпечення соціальної стабільності держави неможлива без гарантування дотримання таких базових передумов, як неухильне дотримання положень чинного нормативно-правового базису, фрормування високого рівня довіри й поваги в суспільстві до державних інституцій, побудови справедливої правоохоронної та судової системи на засадах дотримання принципів презумпції невинуватості та невідворотності покарання за вчинене правопорушення, створення соціально комсортних умов для становлення й всебічного розвитку особистості, структуризації конфрлікту інтересів і забезпечення здорового морально-психологічного клімату в процесі суспільно-економічного обміну.

Етимологія поняття «механізм» агрегує в собі цілісну сукупність структурно-фуннкціональних елементів (форми, методи, інструменти, підсистеми, блоки, надбудови тощо), органічна взаємодія яких стратегічно орієнтована на досягнення наперед чітко визначеної мети. Своєю чергою, специфріка «механізму» проявляється у діалектичній гармонії змісту та форми. Зміст позиціонується крізь розвиток соціально-економічних відносин суспільства, а форма - через призму імплементації його організаційної компоненти. Економічний механізм $€$ способом підтримки реалізації об'єктивних вимог законів у процесі суспільно-економічного обміну. Природа цільового механізму фрормується шляхом узгодження економічних інтересів різних соціальних груп населення на засадах використання адекватних організаційно-економічних інструментів структуризації відносин в умовах лібералізації національної економіки [13, с. 11-16]. Системно виділяють два фрундаментальні підходи до позиціонування механізму в сорері соціально-економічних відносин: 1) структурно-організаційний (визначає механізм через фрорму агрегації окремих його компонент, процесів і явищ); 2) структурнофункціональний (разом 3 організаційною структурою спрямований на досягнення стратегічної мети функціонування економічного механізму) [14, с. 53]. 3 огляду на це, механізм забезпечення соціальної стабільності доцільно позиціонувати через призму агрегованих структурно-фрункціональних компонент та елементів, узгоджена взаємодія яких спрямована на подолання суспільної напруженості в державі, гарантування соціальної справедливості в процесі здійснення господарських трансакцій та забезпечення зрівноваженого розвитку соціально-економічних відносин в умовах динамічних транссрормацій національної економіки.

Особливості фрормування та імплементації механізму забезпечення соціальної стабільності в умовах інтенсиорікації міграційних 
процесів формалізуються в такому: 1) структурно-суункціональна спроможність цільового механізму має передбачати пріоритетні напрями вирівнювання сорормованих дисбалансів соціально-економічного розвитку між Україною та основними державами-реципієнтами мігрантів, зокрема трудових, що потребує орормування масштабної ресурсної підтримки налагодження процесів ефективного фрункціонування цього механізму; 2) забезпеченні стратегічної орієнтованості на динамічне узгодження вітчизняних соціальних стандартів якості життя зі регламентними нормативами та вимогами країн-членів Європейського Союзу; 3) довгостроковий період імплементації прикладних засад механізму забезпечення соціальної стабільності, що потребує фрормування його гнучких властивостей для гарантування можливості оперативного корегування срункціональної структури цільового механізму в просторово-часовому вимірі відповідно до наростаючих викликів і загроз; 4) механізм забезпечення соціальної стабільності в умовах інтенсифрікації міграційних процесів відзначається мультикомпонентним характером, що агрегує в себе фрінансово-економічні, соціальні, інфрормаційні та психологічні аспекти згладжування міграційних аспірацій населення; 5) зменшення інтенсивності міграційних процесів неможливе без формування адекватного соціально-психологічного базису розвитку суспільно-економічних відносин, що передбачає реалізацію послідовної депопулістичної соціально-відповідальної інформаційної політики держави, імплементація прикладних засад якої ускладнюється в умовах загострення проявів загроз гібридного характеру; 6) механізм забезпечення соціальної стабільності держави має передбачати стратегічну орієнтованість на реалізацію перспективних інструментів протидії деструктивним імміграційним процесам в Україні, що загрожують посиленням міжетнічних і міжрелігійних протистоянь; 7) забезпечення соціальної стабільності неможливе без побудови справедливої правоохоронної та судової системи в державі на засадах дотримання принципу верховенства права.

На рис. 1 представлена модель структурно-фрункціональної взаємозалежності процесів забезпечення соціальної стабільності в контексті зменшення активності міграційних процесів в Україні.

Таким чином, ідентифріковані структурнофрункціональні взаємозв'язки, 3 однієї сторони, визначають стратегічні параметри проєктування механізму забезпечення соціальної стабільності в умовах інтенсифрікації міграційних процесів, а з іншої - формують незадіяні ресурсні резерви для реалізації превентивних інструментів протидії деструктивним впливам у соціальній ссрері. Забезпечення ресурснофрункціональної та управлінської спроможності механізму, забезпечення соціальної стабільності в умовах інтенсиорікації міграційних процесів передбачає доцільність дотримання певного етапності дій (рис. 2).

Структурно-фрункціональна архітектоніка механізму забезпечення соціальної стабільності держави в умовах інтенсифрікації міграційних процесів полягає в доцільності формування його дуальних характеристик: з одного боку, фрункціонування цільового механізму має бути націлене на імплементацію структурних змін у соціальній сорері держави, підвищення ефрективності розвитку процесів соціальноекономічних трансорормацій в суспільстві та зменшення міграційної активності населення, а 3 іншого - цей механізм має передбачати можливості для оперативного корегування його організаційно-управлінської та фуункціональної структури у відповідності до змін параметрів ключових детермінант забезпечення соціальної стабільності держави.

Інституційні передумови загострення проблеми соціальної несправедливості в українському суспільстві та зростання міграційної активності населення були закладені ще на початку процесів становлення незалежності України, що супроводжувалися поетапним переходом від командно-адміністративного типу господарювання до засад ринкової економіки та масштабною приватизацію об'єктів державної форми власності. Суттєві прорахунки та помилки, якими супроводжувався процес імплементації структурних рефрорм у 90-их роках XX ст. призвів до незаконного накопичення первинного капіталу та появи окремого олігархічного класу в суспільстві, становлення та фрункціонування якого неможливе без паразитування на національних ресурсах, які $€$ загальним надбанням, що, цілком закономірно, зумовило виникнення та загострення соціального конорлікту в державі. В умовах тотального переважання ресурсної спроможності представників олігархічного класу суспільства соціальна еліта та інтелігенція апріорі були відсторонені від процесів прийняття стратегічних управлінських рішень та фрормування влади в державі, що лише поглибило соціальну несправедливість розподілу матеріальних благ і призвело до активізації міграційних процесів, у т.ч. серед най- 


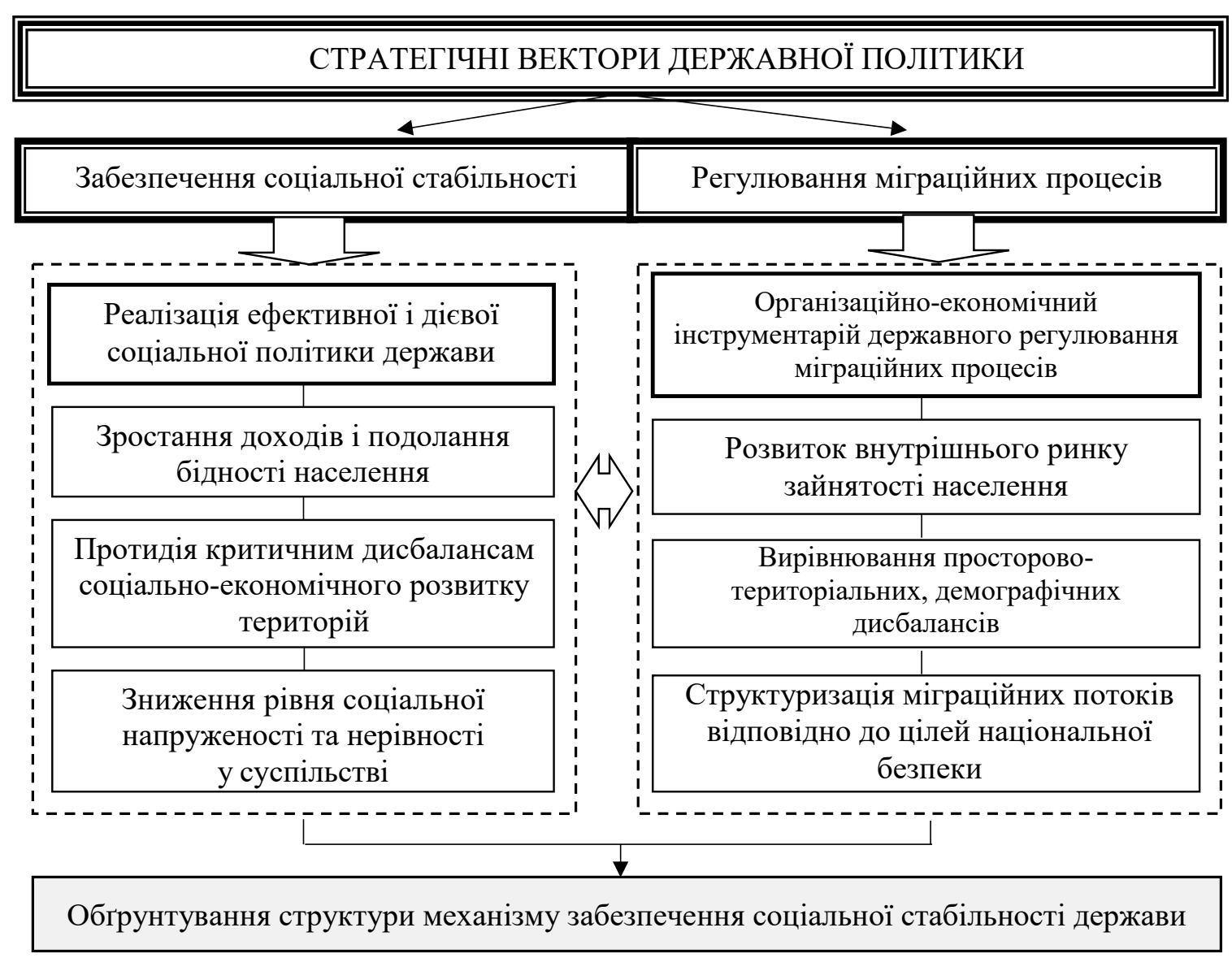

Рис. 1. Модель взаємозалежності процесів забезпечення соціальної стабільності та регулювання міграційних процесів

Джерело: розробка авторів

більш інтелектуальної та мобільної частини населення України. На тлі таких негативних процесів, представники фрінансово-олігархічних структур лише поглибили свої сорери впливу в державі, що дозволило їм отримати стратегічний мандат доступу до використання національних ресурсів. Як наслідок, вони отримали монопольне становище в сорері політики оплати праці (адже, є фрактичними власниками об'єктів потужних виробничо-господарських комплексів національної економіки), що дозволило суттєво обмежити параметри ії зростання в приватному секторі. Таким чином, найбільш квалісрікована частина економічного активного населення держави цілком об'єктивно переорієнтувала свої стратегічні пріоритети на працевлаштування за межами України. Своєю чергою, це стало й одним із чинників обмеження параметрів зростання ефрективності фрункціонування виробничо-господарських комплексів національної економіки, дестабілізувало процеси розвитку соціальної сфери та призвело до погіршення якості людського капіталу.
Імплементація механізму забезпечення соціальної стабільності потребує фрормування адекватного інституційного середовища розвитку соціально-економічних відносин, що відповідає реальним потребам та вимогам часу. Пріоритетним напрямом побудови адекватної інституційної підтримки забезпечення соціальної стабільності держави $€$ дотримання стратегічної орієнтації на оптимізацію структури інституційного базису здійснення соціально-економічних трансформацій в частині збалансування впливу ролі фрормальних і неорормальних інститутів на процеси прийняття управлінських рішень. Адже існуючий надмірний ірраціональний вплив неформального інституційного середовища та застосування практики непоодиноких випадків його реального переважання над фрормальними інститутами в сегменті регулювання соціально-економічних відносин не лише ускладнює забезпечення соціальної стабільності, але й посилює дисонанси соціально-економічних трансорормацій, перешкоджає налагодженню ефективного використання ресурсів 


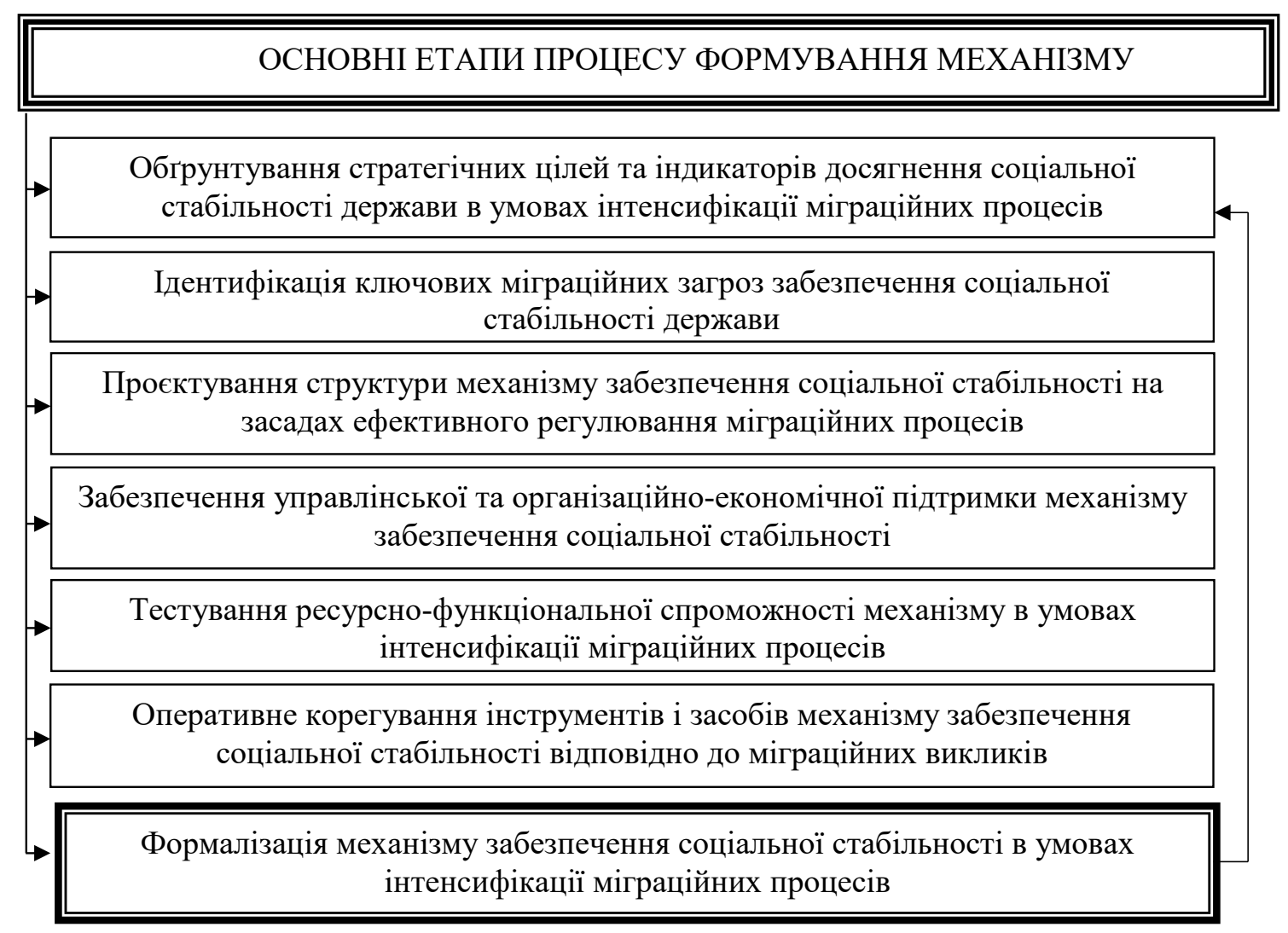

Рис. 2. Послідовність формування механізму забезпечення соціальної стабільності держави в умовах інтенсифрікації міграційних процесів Джерело: розробка авторів

та розвитку стратегічних бізнес-процесів національної економіки, загострює проблему соціальної несправедливості розподілу матеріальних благ у суспільстві, провокує соціальні конорлікти між учасниками суспільно-економічного обміну, підвищує інертний характер розвитку трансорормаційних процесів, що в сукупності посилює мотиваційні механізми та соціально-психологічні стимули в населення до активізації міграційних процесів 3 метою пошуку більш комфортних соціально-трудових умов поза межами України.

Формування раціональної структури співвідношення формальних і нефрормальних інституцій на процеси прийняття управлінських рішень у контексті забезпечення соціальної стабільності в умовах інтенсифрікації міграційних процесів держави передбачає: (1) подолання усталеної практики лобіювання комерційних інтересів окремих фрінансово-промислових груп на найвищих ланках державного управління та регулювання національної економіки, що фрормалізується у прийнятті лояльних до цих груп законних і підзаконних нормативно-правових актів, фрормуванні монопольного доступу до вико- ристання природно-сировинного та фрінансово-економічного потенціалу, паразитуванні потужних бізнес-структур на використанні ресурсів держави, що могли б бути використані на потреби розвитку соціальної сорери; (2) забезпечення чіткого розмежування державних інституцій та бізнесу на засадах формування прозорих конкурсних процедур заміщення вакантних посад в органах державної влади, реформування виборчого інституційного базису в частині обмеження прямого й непрямого доступу представників бізнессередовища до участі у виборчих кампаніях, орормування чітких транспарентних механізмів фрінансування політичних партій та структур; (3) посилення механізмів громадського контролю за процесами прийняття управлінських рішень в сорері соціально-економічних відносин через покращення інституційного соціально-психологічного базису транссрормації національної економіки, підвищення рівня публічності трансакцій в соціальній ссрері, демонополізацію інфрормаційномедійного простору держави, культивування інфрормаційної культури та фрормування критичного мислення в населення. 
Оптимізація структури фрормального та нефрормального інституційного базису сфрормує передумови для підвищення ефективності використання природно-ресурсного потенціалу національної економіки (насамперед, у частині соціальної компоненти), зростання соціальної справедливості розподілу матеріальних благ у суспільстві, подолання проявів девіантної та опортуністичної поведінки населення, покращення базових засад задоволення соціальних потреб громадян, що в сукупності забезпечить нівелювання мотиваційних механізмів і стимулів до активізації міграційних процесів у суспільстві.

Пріоритетним напрямом забезпечення соціальної стабільності в державі та стримування активності населення насамперед у сегменті зовнішньої трудової міграції є захист та відстоювання інтересів працівників через підвищення ефективності використання базових ресурсно-срункціональних можливостей інституту трудових просрспілок та асоціацій. Слід відзначити, що цей інституційний інструментарій $€$ недостатньо задіяним у процеси покращення матеріальних й нематеріальних умов праці трудових колективів, вирівнювання соціальної несправедливості розподілу матеріальних благ та стримування міграційної процесів серед економічного активного населення. Здебільшого такі інституційні утворення $\epsilon$ абсолютно керованими й підконтрольними представництву топ-менеджменту підприємницьких бізнес-структур, що апріорі унеможливлює налагодження процесів їх есрективного розвитку та належного виконання покладених на них стратегічних фрункцій. У зв'язку з цим, доцільним $є$ посилення інтеграції інституту трудових профспілок та асоціацій в процеси забезпечення соціальної стабільності на засадах імплементації механізмів гарантування їх незалежності та самостійності в прийнятті управлінських рішень, підвищення поваги та соціального статусу до цих інституцій серед населення, срормування спільних майданчиків для кооперації ресурсних потужностей, налагодження системної міжсекторальної взаємодії та обміну досвідом у відстоюванні власних інтересів, поширення практики укладання програмних документів 3 роботодавцями, які б передбачали конкретні механізми, засоби та джерела фрінансування заходів щодо покращення соціальних умов працівників, організації можливості надання безоплатної правової допомоги останнім, впровадження прозорих механізмів забезпечення громадського моніторингу та контролю за діяльністю й використанням фрінансових ресурсів профрспілок та трудових асоціацій.

Стратегічним ядром забезпечення соціальної стабільності в державі та зниження міграційної активності населення $€$ потужний середній клас, без створення якого неможливими $€$ побудова розвиненого демократичного суспільства та реалізація якісних поступальних соціально-економічних трансорормацій національної економіки. Формування потужного прошарку середнього класу в державі $€$ фрундаментальним базисом не лише збільшення податкових надходжень до бюджету, вирівнювання наявного диспаритету доходів між найбагатшими і найбіднішими верствами населення, покращення рівня якості життя людей, але й запорукою здійснення якісних структурних перетворень, ресрормування соціального сектору, підвищення відповідальності членів суспільства за розвиток політичних та економічних процесів в країні, посилення громадського контролю за реалізацію прикладних засад державної економічного політики, що в сукупності дозволяє імплементувати ефективні механізми стримування міграційної активності населення. Структурно-фрункціональна роль прошарку середнього класу в забезпеченні соціальної стабільності держави в умовах інтенсифрікації міграційних процесів полягає в тому, що його представники з високою ресурсною спроможністю, специсрікою мислення та менталітету світосприйняття $€$ безпосередніми ініціаторами й рушіями соціальних транссрормацій через неухильне дотримання принципів політичної та економічної свободи особистості, стимулювання економічної активності й самозайнятості, підвищення соціальної відповідальності за прийняті рішення, зацікавленості у забезпеченні політичної та соціальної стабільності та поступального розвитку держави. Середній клас $€$ своєрідним каталізатором демонополізації і посилення конкурентного середовища в сорері суспільно-економічного обміну, що забезпечує підвищення ефрективності фрункціонування виробничо-господарських комплексів національної економіки, стимулює процеси розширеного відтворення та фрормує передумови для якісного задоволення базових інтересів і потреб населення на території тієї країни, де він ссрормований.

Формування потужного прошарку середнього класу суспільства в контексті забезпечення соціальної стабільності та зниження активності міграційних процесів держави потребує забезпечення стратегічної орієнтації на реалізацію таких заходів: 
1) стимулювання самозайнятості та реалізація підприємницьких ініціатив серед представників економічно активного населення держави на засадах використання інструментів державної фрінансово-кредитної підтримки започаткування власного бізнесу; посилення мотиваційних механізмів трансформації неформальних підприємницьких структур у формальні, зміщення соціально-психологічних стимулів у потенційних вітчизняних мігрантів із сегменту отримання статусу-резидента закордоном через використання механізму придбання житла чи реалізації масштабних інвестицій в площину створення та масштабування власного бізнеспроєкту в Україні шляхом реалізації цільових програм фрінансово-економічної підтримки такої категорії осіб; розбудова мережі об'єктів інфрраструктурного забезпечення та надання інорормаційно-консультаційної підтримки суб'єктам господарювання, зокрема у частині здійснення реєстраційних процедур, ведення обліку, оподаткування та адміністрування бізнес-процесів; інтеграція наявної мережі наукових установ і закладів вищої освіти України в процеси розвитку підприємницьких навичок й компетенцій в населення, пошуку лідерівдумок і утвердження в них стимулів до взяття на себе ризику в ході здійснення підприємницької діяльності; продовження практики застосування мораторію на проведення планових перевірок насамперед господарської діяльності новостворених підприємницьких структур, використання інструменту податкових «канікул»; гарантування захисту приватної власності та прав інвестора;

2) імплементація організаційно-економічних і соціально-психологічних інструментів фрормування середнього класу в соціумі представників найбільш масових професій (рядові державні службовці, працівники освітньої ссрери, зайняті в системі охорони здоров'я, військовослужбовці, працівники культури тощо) через реалізацію системної інфрормаційної кампанії фрормування поваги та підвищення ролі соціального статусу представників цих професій в суспільстві; встановлення меж граничного рівня обсягів мінімального бюджетного фрінансування в цих сорерах; підвищення рівня оплати праці, шляхом вирівнювання наявного диспаритету в питанні матеріального стимулювання між бюджетним і приватним сектором, у тому числі на засадах використання коригуючих коефріцієнтів підвищення посадових окладів Єдиної тарифної сітки, що частково дозволить подолати наявну соціальну несправедливість в оплаті праці зайня- тих у цих сорерах відповідно до їх профресійних компетенцій та квалісрікацій. Все це в сукупності зумовить посилення соціальної стабільності, що формалізуватиметься в такому: збільшення обсягів податкових надходжень до бюджету (працівники бюджетної сорери, апріорі, отримують легальні доходи, що приведе до зростання обсягів відрахувань до фрондів соціального страхування країни), нівелювання стимулів до трудової міграції закордон представників інтелектуально-кадрового потенціалу держави (насамперед серед працівників системи охорони здоров'я та освітньої сфери), покращення соціально-психологічного базису в суспільстві та підвищення керованості процесів забезпечення соціальної стабільності держави, адже працівники цих сорер через особисту комунікацію інтегрують цілісний соціум і мають визначальний вплив на формування суспільної думки;

3) стимулювання підприємницької активності сільського населення насамперед у площині формування потужного пласту фермерства, який $€$ значним незадіяним резервом подолання стагнації соціально-економічного розвитку сільських територій, згладжування просторово-територіальних дисбалансів, зменшення безробіття, а отже й міграційної активності в сільській місцевості. Стратегічна роль фермерства у формуванні середнього класу в сільській місцевості обґрунтовується 3 огляду на ресурсні масштаби вітчизняних сільських територій: 42,7 млн га сільськогосподарських угідь складає 68,8 \% загальної території України [15], а сільське населення налічує 12,6 млн осіб (30,4 \% від його загальної чисельності) [16]. У зв'язку з цим доцільною $€$ орієнтація на забезпечення підтримки процесів трансорормації нетоварних господарств населення у товарні форми господарювання; реалізацію інструментів надання цільових пільгових кредитів фермерам на придбання сільськогосподарської техніки; розвиток кооперативних та інтеграційних процесів на селі; пошук й становлення місцевих лідерів насамперед серед сільської молоді, що спроможні інтегрувати набуті інноваційні знання у практику господарювання на селі. Становлення фермерського класу в сільській місцевості дозволить подолати процеси соціальної деградації сільських територій та «вимирання» сіл, покращити зайнятість на селі, зменшити міграційну активність сільського населення, підвищити соціальну відповідальність за використання природноресурсного потенціалу сільських територій в процесі господарювання. 
Забезпечення соціальної стабільності в умовах інтенсифрікації міграційних процесів неможливе без імплементації есрективних інструментів детінізації фрункціонування виробничо-господарських комплексів національної економіки. Адже надмірний рівень тінізації національної економіки обмежує параметри формування фрінансово-ресурсних потужностей для вирівнювання диспаритету доходів громадян, стримує реалізацію ефективної політики захисту найбільш незахищених верств населення та ускладнює подолання соціальних протиріч у ході суспільно-економічного обміну. Для цього необхідним $є$ дотримання стратегічної орієнтації на: впровадження механізмів ефективного моніторингу та контролю реальних масштабів господарювання суб'єктів бізнесу та здійснення їх господарських трансакцій (у тому числі, через пришвидшення темпів впровадження обов'язкового використання реєстраторів розрахункових операцій); боротьбу 3 усталеною практикою виплати заробітних плат у «конвертах» шляхом реалізації системної інфрормаційної кампанії роз'яснення населенню реальних ризиків отримання тіньових доходів i безперспективності для них можливості отримання адекватного пенсійного забезпечення в похилому віці; покращення рівня довіри в представників бізнесу до органів державної влади через інструменти зниження корупційного навантаження на діяльність підприємницьких структур і зменшення бюрократичного тиску чиновників; забезпечення прозорості та прогнозованості фоомування інституційно-правового базису господарювання, у тому числі в ссрері податкового навантаження на суб'єктів бізнесу; культивування високого рівня податкової культури, як представників підприємницького середовища, так і безпосередніх споживачів їх продуктів і послуг.

Структурної модернізації потребують прикладні засади реалізації державної соціальної політики. 3 однієї сторони, державні інституції повинні посилити соціальну спрямованість та есрективність використання бюджетних ресурсів, а з іншої - доцільним $€$ гарантування справедливості в процесі імплементації соціальної політики. Адже, загальновідомим є той фракт, що практика використання бюджетно-ресурсного базису соціальної сфрери не завжди відповідає принципам суспільної доцільності та пріоритетності забезпечення соціальної стабільності держави. Таким чином, структурна модернізація соціальної політики в умовах інтенсифрікації міграційних процесів має бути спрямована на:
- впровадження превентивних механізмів запобігання соціальному утриманству в суспільстві й подолання практики паразитування окремих верств населення на споживанні бюджетних ресурсів, що обмежує параметри ефективності використання бюджетних коштів і нівелює базові засади соціальної справедливості розподілу матеріальних благ у суспільстві;

- посилення механізмів соціального захисту найбільш вразливих категорій населення (діти-сироти, особи 3 інвалідністю, багатодітні та малозабезпечені сім'ї та ін.) шляхом наближення стандартів надання розміру соціальної допомоги до граничного рівня мінімальної заробітної плати в державі;

- системну зміну підходів до надання фрінансової підтримки населенню на випадок настання тимчасового безробіття через нівелювання ризиків виникнення зловживань 3 боку отримувачів такої допомоги, покращення фрункціональної взаємодії регіональних центрів зайнятості з приватними кадровими агенціями, спрямування частини коштів із сегменту соціального споживання в площину перепідготовки та підвищення квалісрікації кадрів, відповідно до реальних потреб ринку праці;

- вдосконалення пенсійного забезпечення на засадах оптимального поєднання елементів солідарної та накопичувальної системи, наближення розміру мінімальної пенсії до рівня мінімальної заробітної плати, чіткої структуризації передумов для можливості дострокового виходу на пенсію, подолання разючого розриву між розміром найменшої та найбільшої пенсії в державі.

Стратегічним базисом забезпечення соціальної стабільності в умовах інтенсифрікації міграційних процесів $€$ форомування сприятливого соціально-психологічного базису розвитку суспільно-економічних відносин, що передбачає необхідність фрормування високого рівня довіри таповаги до державнихінституцій, забезпечення неухильного дотримання принципу верховенства права та законності, недопущення конорліктного середовища в соціумі через мінімізацію ризиків виникнення конфрлікту інтересів, культивування ідеї дотримання високих стандартів моральних принципів у сфрері суспільних відносин. Визначальне місце у фокусі вирішення цієї проблеми посідає система освіти, ресрормування якої має бути націлене не лише на розвиток професійних компетенцій та навиків людини, але й формування високих морально-етичних особистісних норм. Поряд з цим, важливою 
$€$ побудова мотиваційних механізмів і стимулів в української молоді, що здобула освіту закордоном, до повернення, працевлаштування та реалізації ії набутих інноваційних знань й досвіду безпосередньо в Україні. Для цього необхідною $€$ реалізація комплексної програми так званого «соціального ліфрту» для молоді, що гарантувала б можливості справедливого кар'єрного зростання в системі державних інституцій та надання для цих категорій осіб високого соціального статусу в суспільстві, у тому числі через використання ресурсного інструментарію соціальних пільг.
Ефективне регулювання міграційної активності населення неможливе без культивування в суспільстві ідеї міцного інституту сім'ї, утвердження культурно-духовних і моральних принципів, розвитку почуття національного патріотизму, фрормування високого рівня соціальної свідомості та відповідальності в населення. Своєю чергою, це потребує налагодження ефрективного соціального діалогу між державними інституціями, релігійними організаціями, суспільством та конкретною особистістю, в умовах якого чітко позиціонується роль кожного громадянина та його участь у

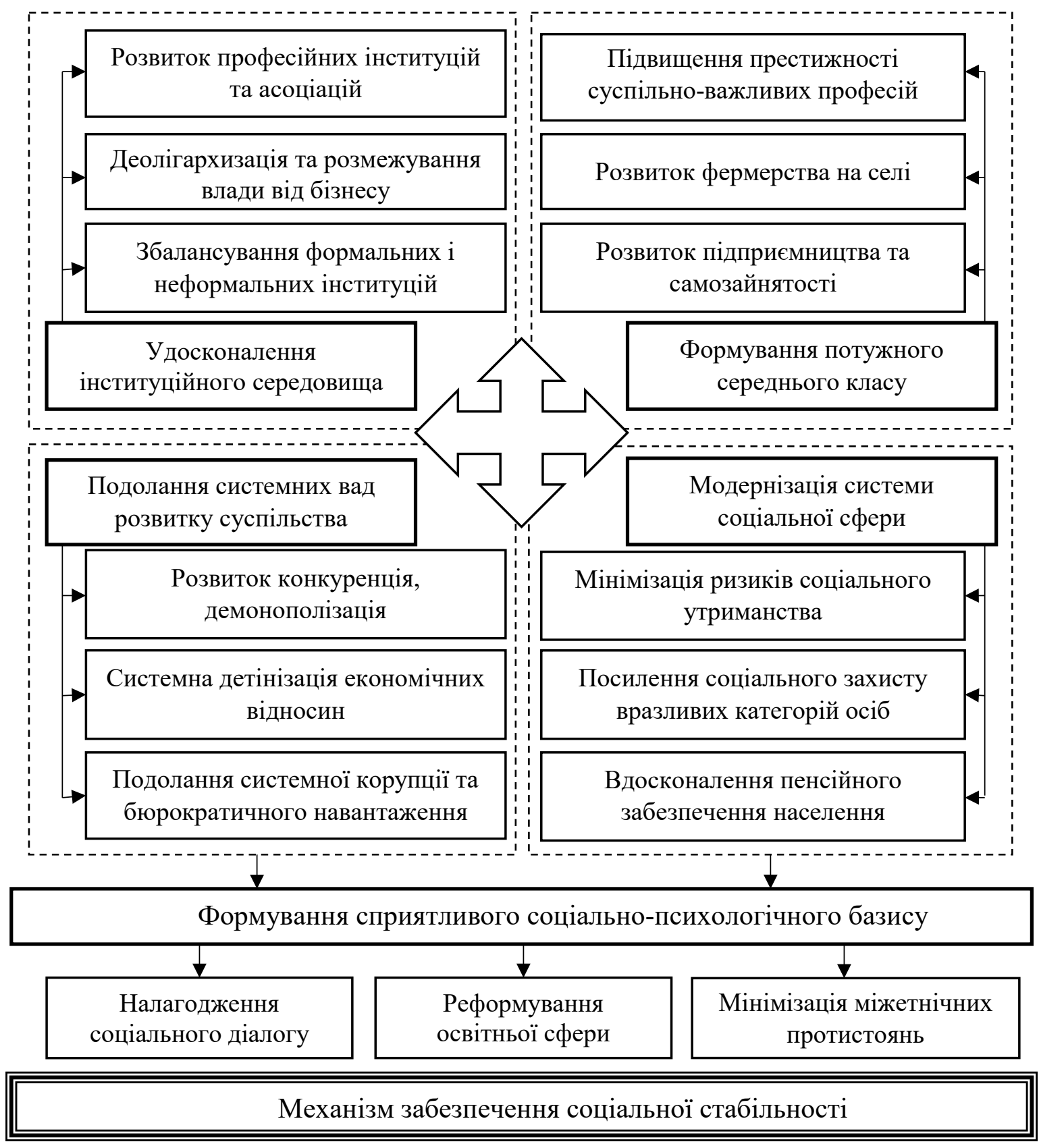

Рис. 3. Структура механізму забезпечення соціальної стабільності України в умовах інтенсифікації міграційних процесів 
процесі соціально-економічних трансформацій національної економіки. Не менш важливою $€$ реалізація послідовної інсрормаційної політики фрормування сприятливого соціально-психологічного базису мінімізації ризиків виникнення міжетнічних та міжрелігійних конорліктів, що потребує забезпечення стратегічної орієнтації на імплементацію в суспільстві ідейних положень міжнаціональної та міжконфресійної толерантності, фрормування високої рівня поваги до культурних звичаїв і традицій, впровадження ефективних санкційних механізмів боротьби з проявами суспільної ненависті на тлі етнічної, расової чи релігійної приналежності.

На рис. 3 представлено агрегований механізм забезпечення соціальної стабільності держави в умовах інтенсифрікації міграційних процесів. Імплементація розробленого механізму забезпечення соціальної стабільності в умовах інтенсифрікації міграційних процесів сорормує передумови для зниження соціальної напруженості, підвищення справедливості розподілу матеріальних благ і зменшення рівня конорліктного середовища в соціумі, що в кінцевому випадку трансорормується в посилення мотиваційних стимулів у населення до реалізації життєвих стратегій в Україні.

Висновки. Інтенсифрікація міграційних процесів об'єктивно позначається на ключових характеристиках соціальної системи. Відпо- відно, для мінімізації ризиків і загроз соціальній безпеці України необхідне фрормування ефрективного механізму державної політики забезпечення соціальної стабільності.

Важливо, щоб інструменти та засоби такого механізму фокусувалися навколо фрормування і посилення таких базисних засад, як соціально-інституційне середовище (узгодження формальних і нефрормальних інститутів, розмежування влади та бізнесу, посилення ролі інституту профрспілок і асоціацій у вирішенні трудових конфрліктів, покращення механізмів громадського контролю); потужний пласт середнього класу в суспільстві (стимулювання підприємницьких ініціатив і самозайнятості, підвищення престижності суспільно-важливих профресій, підтримка розвитку фрермерського руху на селі); детінізація процесів суспільноекономічного обміну (посилення контролю за реальними масштабами господарських трансакцій, протидія тіньовим доходам населення, зменшення корупції та бюрократичного тиску); структурна модернізація соціальної політики (унеможливлення практики соціального утриманства, посилення соціального захисту населення, ресормування пенсійної системи); сприятливий інституційно-психологічний базис (впровадження соціального діалогу, ресрормування системи освіти, нівелювання ризиків виникнення міжетнічних і міжконфесійних консрліктів).

\section{СПИСОК ВИКОРИСТАНИХ ДЖЕРЕЛ:}

1. Барна М. Ю., Рущишин Н. М. Структурні характеристики розвитку економіки: системно-аналітичний зріз. Міжнародний науковий журнал «Інтернаука». Серія : «Економічні науки». 2020. Том 1. № 12(44). С. 23-30.

2. Bettin G., Presbitero A. F., Spatafora K. Remittances and vulnerability in developing countries. InIMF Working Paper No. WP/14/13; International Monetary Fund: Washington, DC, USA, 2014.

3. Donou-Adonsou F., Lim S. An empirical analysis of remittance flows into West African Economic and Monetary Union: A panel time-series approach. Applied Economics, 2015, 48, 1-12. URL: https://doi.org/10.1080/00036846. 2015.1093080

4. Kumar R. R., Stauvermann P. J., Kumar N. N., Shahzad S. J. H. Revisiting the threshold effect of remittances on total factor productivity growth in South Asia: A study of Bangladesh and India. Applied Economics, 2018, 50, 2860-2877. URL: https://doi.org/10.1080/00036846.2017.1412074

5. Libanova E. Labour migration from Ukraine: key features, drivers and impact. Economics and Sociology, 2019, 12(1), 313-328. DOI: 10.14254/2071-789X.2019/12-1/19

6. Vasyltsiv T., Lupak R., Kunytska-lliash M. Social security of Ukraine and the EU: aspects of convergence and improvement of migration policy. Baltic Journal of Economic Studies, 2019, 5(4), 50-58. DOI: https://doi.org/10.30525/ 2256-0742/2019-5-4-50-58

7. Васильців Т. Г., Шехлович А., Васильців В. Г. Фінансово-економічні інструменти стимулювання розвитку IT-ссрери України. Економічний дискурс. 2017. Вип. 4. С. 128-136.

8. Волоско Я. О. Адміністративно-правове регулювання трудової міграції в умовах транссормації економіки України : дис. на здобуття наук. ступеня канд. юрид. наук : спец. 12.00.07 «Адміністративне право і процес; фрінансове право; інсоормаційне право». Львів, 2015. 181 с.

9. Мульска О. П. Балансування ринку праці в умовах підвищеної міграційної активності населення. Соціально-економічні проблеми сучасного періоду України. Збірник наукових праць. 2019. Вип. № 1(135). С. 59-65. 
10. Мульска О. П. До фрормування системи соціального захисту трудових мігрантів. Економіка та держава. 2015. № 7. С. 54-57.

11. Регіональна міграційна політика та механізми її реалізації / НАН України, Інститут регіональних досліджень; Наук. ред. У. Я. Садова. Львів, 2011. 380 с.

12. Рущишин Н. М. Структурні реформи як базис сталого та збалансованого розвитку системи національного господарства. Бізнес-навігатор. 2018. № 6(49). С. 264-269.

13. Лузан Ю. Я. Організаційно-економічний механізм забезпечення розвитку агропромислового виробництва України : монографрія. Київ : ННЦ IAE, 2010. 485 с.

14. Криклій О. А., Маслак Н. Г. Визначення сутності та структури фрінансового механізму управління фріліями банку. Вісник Української академії банківської справи. 2007. № 1(22). С. 53-58.

15. Державна служба статистики України. URL: http://www.ukrstat.gov.ua/

16. Демограсрічний паспорт території. Державна служба статистики України. URL: http://database.ukrcensus.gov.ua/ Mult/Dialog/statfile1_c_files/pasport1.htm

\section{REFERENCES:}

1. Barna M. Ju., Rushhyshyn N. M. (2020) Strukturni kharakterystyky rozvytku ekonomiky: systemno-analitychnyj zriz [Structural characteristics of economic development: system-analytical section]. Mizhnarodnyj naukovyj zhurnal «Internauka». Serija: «Ekonomichni nauky», no. 12(44), pp. 23-30.

2. Bettin G., Presbitero A. F., Spatafora K. (2014) Remittances and vulnerability in developing countries. InIMF Working Paper No. WP/14/13; International Monetary Fund: Washington, DC, USA.

3. Donou-Adonsou F., Lim S. (2015) An empirical analysis of remittance flows into West African Economic and Monetary Union: A panel time-series approach. Applied Economics, 48, 1-12. Available at: https://doi.org/10.1080/ 00036846.2015.1093080

4. Kumar R. R., Stauvermann P. J., Kumar N. N., Shahzad S. J. H. (2018) Revisiting the threshold effect of remittances on total factor productivity growth in South Asia: A study of Bangladesh and India. Applied Economics, no. 50, pp. 2860-2877. Available at: https://doi.org/10.1080/00036846.2017.1412074

5. Libanova E. (2019) Labour migration from Ukraine: key features, drivers and impact. Economics and Sociology, no. 12(1), pp. 313-328. DOI: 10.14254/2071-789X.2019/12-1/19

6. Vasyltsiv T., Lupak R., Kunytska-lliash M. (2019) Social security of Ukraine and the EU: aspects of convergence and improvement of migration policy. Baltic Journal, no. 5(4), pp. 50-58.

7. Vasyljciv T. Gh., Shekhlovych A., Vasyljciv V. Gh. (2017) Finansovo-ekonomichni instrumenty stymuljuvannja rozvytku IT-sfery Ukrajiny [Financial and economic instruments to stimulate the development of the IT sphere of Ukraine]. Ekonomichnyj dyskurs, no. 4, pp. 128-136.

8. Volosko Ja. O. (2018) Administratyvno-pravove reghuljuvannja trudovoji mighraciji v umovakh transformaciji ekonomiky Ukrajiny [Administrative and legal regulation of labor migration in the conditions of transformation of the economy of Ukraine]. Candidate's legal sciences. Lviv. (in Ukrainian)

9. Muljska O. P. (2019) Balansuvannja rynku praci v umovakh pidvyshhenoji mighracijnoji aktyvnosti naselennja. Socialjno-ekonomichni problemy suchasnogho periodu Ukrajiny [Balancing the labor market in conditions of increased migration activity of the population]. Zbirnyk naukovykh pracj, no. 1(135), pp. 59-65.

10. Muljska O. P. (2015) Do formuvannja systemy socialjnogho zakhystu trudovykh mighrantiv [Before the formation of the system of social protection of migrant workers]. Ekonomika ta derzhava, no. 7, pp. 54-57.

11. Reghionaljna mighracijna polityka ta mekhanizmy jiji realizaciji 2011 [Regional migration policy and mechanisms for its implementation] / NAN Ukrajiny, Instytut reghionaljnykh doslidzhenj; Nauk. red. U. Ja. Sadova. Lviv, 380 p.

12. Rushhyshyn N. M. 2018 Strukturni reformy jak bazys stalogho ta zbalansovanogho rozvytku systemy nacionaljnogho ghospodarstva [Structural reforms as a basis for sustainable and balanced development of the national economy]. Biznes-navighator, no. 6(49), pp. 264-269.

13. Luzan Ju. Ja. 2010 Orghanizacijno-ekonomichnyj mekhanizm zabezpechennja rozvytku aghropromyslovogho vyrobnyctva Ukrainy [Organizational and economic mechanism for ensuring the development of agro-industrial production of Ukraine]: monoghrafija. Kyiv: NNC IAE. (in Ukrainian)

14. Kryklij O. A., Maslak N. Gh. (2007) Vyznachennja sutnosti ta struktury finansovogho mekhanizmu upravlinnja filijamy banku [Defining the essence and structure of the financial mechanism of bank branch management]. Visnyk Ukrajinsjkoji akademiji bankivsjkoji spravy, no. 1(22), pp. 53-58.

15. Derzhavna sluzhba statystyky Ukrajiny [State Statistics Senvice of Ukraine]. Retrieved from: http://www.ukrstat.gov.ua/

16. Demoghrafichnyj pasport terytoriji [Demographic passport of the territory]. Derzhavna sluzhba statystyky Ukrainy. Retrieved from: http://database.ukrcensus.gov.ua/Mult/Dialog/statfile1_c_files/pasport1.htm 